spores of three-spore asci represent three out of the four products of meiosis.

The present work indicates that Mendelian analysis, as distinct from tetrad analysis, is possible in yeast, and in certain cases it is labour saving.

Department of Genetics,

$$
\text { E. A. BEvan* }
$$

University of Glasgow. Oct. 16.

* Present address : Department of Zoology, Dartmouth collegc, Hanover, N.H., U.S.A.

\section{Absorption of Water by the Egg of the Garden Chafer, Phyllopertha horticola L.}

MANY insect eggs absorb water from the environment ${ }^{1}$. Absorption usually occurs over a limited period during the early stages of development. The mechanism of the control of absorption is being studied in the egg of the garden chafer.

In Nature, the female chafer lays her eggs in June ; about the middle of July the larvæ hatch and begin to feed on the grass roots. For $3 \frac{1}{2}$ months the grubs feed and grow, moulting twice. The full-grown third instar larva goes into hibernation about the end of October, resting in a small cavity $3-5$ in. deep in the soil. Pupation occurs towards the end of April and the beetle emerges from the pupal skin at the end of May. After staying in the hibernation cavity for a few more days, to complete development, the adult emerges from the soil to mate. The female returns to the soil to lay her eggs.

When laid, the egg is usually a white prolate spheroid, weight $1 \mathrm{mgm}$., length $1.5 \mathrm{~mm}$. and diameter $1 \mathrm{~mm}$. approximately. On the third day after laying, at $20^{\circ} \mathrm{C}$. and 100 per cent relative humidity, the egg begins to absorb water and by the eighth day reaches a weight of $3 \mathrm{mgm}$., measuring about $2 \mathrm{~mm}$. $\times 1.5 \mathrm{~mm}$. The weight then remains at that level until the larva hatches on the twentieth day.

The absorption period, from the third to the eighth day, is accompanied by changes in the rate of loss of water of the egg when desiccated. On the first day after laying, the egg loses water (in 0 per cent relative humidity) at the rate of $1 \mathrm{mgm} . / \mathrm{sq} . \mathrm{cm} . / \mathrm{hr}$. On the second day the rate of water loss increases, rising to a maximum, on the fifth day, of about $20 \mathrm{mgm}$. $/ \mathrm{sq} . \mathrm{cm}$. $/ \mathrm{hr}$. Thereafter the rate falls and by the tenth day has dropped to $0.7 \mathrm{mgm} . / \mathrm{sq} . \mathrm{cm} . / \mathrm{hr}$. It is well known that insect-covering membranes show asymmetry in that water passes across them more rapidly in one direction than the other ${ }^{2}$. Thus the rate at which the egg loses water tells us little about the rate at which water is able to pass in through the egg shell. However, changes in rate of loss of water will reflect changes in permeability to inward flow of water.

Changes have also been observed in the thickness of the egg shell. The shell of the new-laid egg is about $8 \mu$ thick. By the end of the absorption period. the shell is nearly $15 \mu$ thick. This increase may perhaps be a swelling of the shell material itself, but seems more likely to be due to the addition of material by the embryo.

These observations suggest a pussive mecnanism by which the uptake of water is regulated: the egg is laid down having a relatively waterproof layer in the shell. This is broken down by the developing embryo ; the egg can then absorb water apparently passively due to its high osmotic pressure. When the egg has swollen to its full size, the shell is re-waterproofed by the embryo and absorption stops. Roger Latghuin

Agriculture Department, King's College,

Newcastle upon Tyne. Aug. 28.

1 Buxton, P. A., Biol. Rev., 7, 275 (1932). Matthee, J. J., tnion of S. Africa, Sici. Bull., No.' 316 (1951).

${ }^{2}$ Hurst, H., Discuss. Farad. Soc., No, 3, 193 (1948).

\section{Nocturnal Mating in Tæniorhynchus (Mansonioides) uniformis (Theobald)}

Mating in Toniorhynchus (Mansonioides) uniformis (Theobald) was observed taking place on the night of December 7, 1951, between $18.30 \mathrm{hr}$. and $22.30 \mathrm{hr}$., while all-night trapping of mosquitoes was in progress at a cattle-shed in a village on the outskirts of Colombo. On this night it was quite dark by $18.15 \mathrm{hr}$., but for the light of the moon which was two days after the first quarter. Mating activity took place in three stages. In the first and third stages, which lasted from $18.30 \mathrm{hr}$. until $19.30 \mathrm{hr}$. and during $20.30 \mathrm{hr},-22.30 \mathrm{hr}$. respectively, mating was in actjve progress. In between these two periods of considerable activity there occurred a lull from $19.30 \mathrm{hr}$. until $20.30 \mathrm{hr}$., during which far fewer pairs of mosquitoes were observed copulating, and relatively few males were found coming into the trap. But at no time during this period of four hours was mating not in progress, and 292 females and 195 males were caught; these numbers represented only a small proportion of $T$. uniformis in the trap, for owing to great activity among the mosquitoes, catching was seriously interfered with. No mating occurred after $22.30 \mathrm{hr}$.

Three types of mating behaviour were observed occurring simultaneously. In the first, males were copulating with blood-fed females which were resting on the trap-net. In the second, males and females were seen flying in copulo, the females being in the lead, while in the third type males were seen to copulate with females in flight.

Although observations have been carried out at this site on more than a hundred occasions, no swarming of males of $T$. uniformis has ever been encountered, while mating only occurred on this particular night. These observations on $T$. uniformis appear to be the first record of nocturnal mating of a mosquito in Nature. It took place over a period of four hours and in the absence of any swarming by the males.

A more complete account will be published elsewhere.

\section{S. H. JAYEWICKREME}

Medical Research Institute,

Colombo 8. Sept. 17.

\section{Absence of the Sickle Cell Trait in the Bushmen of South-West Africa}

DURING the course of a general survey of the black races of southern Africa for the sickle cell traitthe results of which will be published elsewhere -...n opportunity arose of examining blood specimens from 118 Bushmen. Fifty-eight specimens were obtained from Barakwenga or River Bushmen living in the western section of the Caprive Zipfel in the north-east of South-West Africa. The remainder were from south of the Okavango River near the western border of Bechuanaland. 